\begin{tabular}{|c|c|}
\hline Title & Hydrodeoxygenation of phenols as lignin models under acid-free conditions with carbon-supported platinum catalysts \\
\hline Author(s) & Ohta, Hidetoshi; Kobayashi, Hirokazu; Hara, Kenji; Fukuoka, A tsushi \\
\hline Citation & $\begin{array}{l}\text { Chemical Communications, 47(44), 12209-12211 } \\
\text { https://doi.org/10.1039/c1cc14859a }\end{array}$ \\
\hline Issue Date & 2011-11-28 \\
\hline Doc URL & http:/hdl.handle.net/2115/50126 \\
\hline Rights & Chem. Commun., 2011, 47, 12209-12211 - Reproduced by permission of The Royal Society of Chemistry (RSC) \\
\hline Type & article (author version) \\
\hline File Information & CC47-44_12209-12211.pdf \\
\hline
\end{tabular}

Instructions for use 


\title{
Hydrodeoxygenation of phenols as lignin models under acid-free conditions with carbon-supported platinum catalysts
}

\author{
Hidetoshi Ohta, Hirokazu Kobayashi, Kenji Hara, and Atsushi Fukuoka* \\ Received (in $X X X, X X X)$ Xth $X X X X X X X X X 200 X$, Accepted Xth $X X X X X X X X X 200 X$ \\ ${ }_{5}$ First published on the web Xth $X X X X X X X X X 200 X$ \\ DOI: $10.1039 / b 000000 x$
}

\begin{abstract}
Carbon-supported Pt catalysts are highly active and reusable for the aqueous-phase hydrodeoxygenation of phenols as lignin models without adding any acids. It is suggested that $\mathrm{Pt} /$ carbon ${ }_{10}$ facilitates the hydrogenation of phenols and the hydrogenolysis of the resulting cyclohexanols.
\end{abstract}

Bio-oils derived from lignocellulosic biomass have attracted significant attention as a feedstock for the renewable 15 production of biofuels that are an promising alternative to fossil fuels. ${ }^{1}$ Lignin is the second most abundant natural organic polymer consisting of methoxylated phenylpropane units, which is a rich source of phenolic bio-oils. ${ }^{2,3}$ However, the bio-oils are highly oxygenated, thus leading to undesirable 20 properties and chemical instability. Therefore, the upgrading is necessary for the utilization of bio-oils., ${ }^{1,3}$ Hydrodeoxygenation with supported CoMo and NiMo sulfides is the most common process for the upgrading of such bio-oils into transportation fuels. ${ }^{4}$ However, these systems suffer from 25 coke formation, sulfur contamination, and water-induced catalyst deactivation. ${ }^{5}$ For that reason, non-sulfided catalyst systems have been developed for the hydrodeoxygenation of phenolic bio-oils. ${ }^{6}$

Recently, Kou and Lercher et al. reported the aqueous30 phase hydrodeoxygenation of phenolic bio-oils into cycloalkanes by using $\mathrm{Pd} / \mathrm{C}$ with a liquid acid catalyst $\left(\mathrm{H}_{3} \mathrm{PO}_{4}\right)^{7}$ The reaction consists of metal-catalyzed hydrogenation of aromatic ring/cycloalkene and acidcatalyzed dehydration of cycloalkanol to cycloalkene. 35 However, the addition of acid catalyst is necessary and the recovering of the acid from the reaction mixture is difficult. The combination of RANEY Ni and a solid acid $\left(\mathrm{Nafion} / \mathrm{SiO}_{2}\right)$ has also been reported, ${ }^{8}$ but the thermal stability of Nafion is not sufficient under at high temperature 40 (typically $300{ }^{\circ} \mathrm{C}$ ). Accordingly, the development of new heterogeneous catalysts with high activity and durability is still important for the hydrodeoxygenation reaction.

In the present study, we found that readily available carbonsupported Pt catalysts showed high activity and durability in 45 the hydrodeoxygenation of phenols without adding any acid catalysts (Scheme 1). Here, the deoxygenation of phenols includes the hydrogenation of aromatic rings and the subsequent hydrogenolysis of the $\mathrm{C}-\mathrm{O}$ bond of cyclohexanols.

A series of carbon-supported $\mathrm{Pt}$ catalysts $(2 \mathrm{wt} \% \mathrm{Pt}$ 50 loading) were prepared by a typical impregnation method using an aqueous solution of $\mathrm{H}_{2} \mathrm{PtCl}_{6}$ with different types of carbon materials such as $\mathrm{AC}(\mathrm{N})$ and $\mathrm{AC}(\mathrm{W})$ (activated carbons from Norit and Wako), CMK-3 (mesoporous carbon), ${ }^{9}$ MWCNT (multi-walled carbon nanotube, TCI), and ${ }_{55}$ BP2000 (carbon black, Cabot). The catalysts were characterized by $\mathrm{N}_{2}$ adsorption, XRD, and TEM analyses. The characterization data are summarized in Table S1 and Fig. S12 in $\mathrm{ESI} \uparrow$.

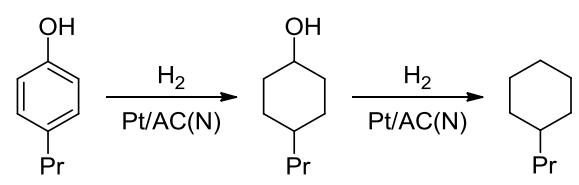

60 Scheme 1 Reaction pathway for the hydrodeoxygenation of phenols.

The catalytic performances of the carbon-supported $\mathrm{Pt}$ catalysts were examined in the hydrodeoxygenation of 4propylphenol (1) in water at $280{ }^{\circ} \mathrm{C}$ under $4 \mathrm{MPa} \mathrm{H}_{2}$ (initial pressure at $\mathrm{RT}$ ) (Table 1). $\mathrm{Pt} / \mathrm{AC}(\mathrm{N})$ catalyst, which was ${ }_{65}$ prepared from easily available $\mathrm{AC}(\mathrm{N})$ support, showed remarkably high catalytic activity to give propylcyclohexane (2) in $97 \%$ yield (entry 1, Fig. S3 in ESI $\dagger$ ). Pt/CMK-3 and $\mathrm{Pt} / \mathrm{MWCNT}$ also afforded $\mathbf{2}$ in slightly lower yields (entries 2-3). Pt/AC(W) gave 2 in $73 \%$ yield and 470 propylcyclohexanol (3) in $16 \%$ yield (entry 4 ), suggesting the reaction pathway as shown in Scheme 1. By contrast, Pt/BP2000 provided markedly lower conversion of $1(16 \%)$ and yield of 2 (9\%) (entry 5). Oxide-supported $\mathrm{Pt} / \mathrm{ZrO}_{2}$, $\mathrm{Pt} / \mathrm{TiO}_{2}$, and $\mathrm{Pt} / \mathrm{CeO}_{2}$ were moderately effective for this 75 reaction, affording 2 in good yields (entries 6-8). In these cases, propylbenzene (5) was also obtained in 3-10\% yield probably via the direct hydrogenolysis of $\mathbf{1}$. In sharp contrast, $\mathrm{Pt} / \gamma-\mathrm{Al}_{2} \mathrm{O}_{3}$ gave no reaction due to the structural transformation of $\gamma-\mathrm{Al}_{2} \mathrm{O}_{3}$ into boehmite $[\mathrm{AlO}(\mathrm{OH})]$ during 80 the reaction (entry 9, Fig. S4 in ESI† $)$. Besides, Rh, Ru, and Pd catalysts supported on $\mathrm{AC}(\mathrm{N})$ were also used (entries 10 12), but these catalysts gave lower yields of 2 than Pt/AC(N) catalyst. ${ }^{10}$ With the highly active $\mathrm{Pt} / \mathrm{AC}(\mathrm{N})$ catalyst, a reaction of $\mathbf{1}$ on a gram-scale was carried out with a high substrate to ${ }_{85}$ catalyst molar ratio $(\mathrm{S} / \mathrm{C})$ of 1000 at $280{ }^{\circ} \mathrm{C}$ for $2 \mathrm{~h}$, which afforded $\mathbf{2}$ in $>99 \%$ yield (entry 13). In the large-scale reaction, an excellent yield (>99\%) of $\mathbf{2}$ was also obtained even at $240{ }^{\circ} \mathrm{C}$ with a longer reaction time of $10 \mathrm{~h}$ (entry 14). Furthermore, $\mathrm{Pt} / \mathrm{AC}(\mathrm{N})$ also catalyzed the conversion of $\mathbf{1}$ into ${ }_{90} 2$ without water-solvent (entry 15), which shows that the catalyst is applicable both in water and under the solvent-free conditions. 
Table 1 Hydrodeoxygenation of 4-propylphenol (1) with supported metal catalysts. ${ }^{a}$

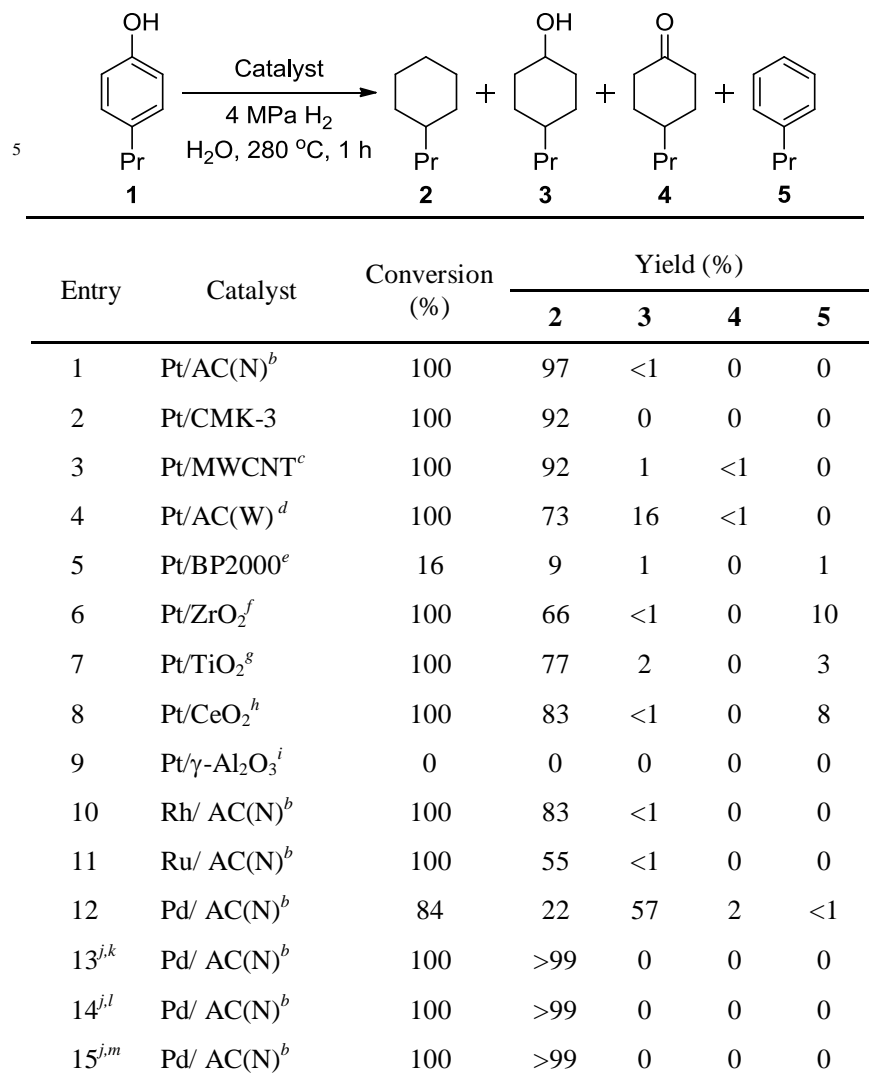

${ }^{a}$ Reaction conditions: 4-propylphenol $1(2.0 \mathrm{mmol}, 272 \mathrm{mg})$, catalyst (2 wt $\%$ metal, $\mathrm{S} / \mathrm{C}=200)$, water $(40 \mathrm{ml})$, initial $\mathrm{H}_{2}$ pressure at $\mathrm{RT}=4 \mathrm{MPa}$, $280{ }^{\circ} \mathrm{C}, 1 \mathrm{~h}$, stirred at $600 \mathrm{rpm}^{b}$ Activated carbon, SX Ultra (Norit). ${ }^{c}$

10 Multi-walled carbon nanotube (TCI). ${ }^{d}$ Activated carbon (Wako). ${ }^{e}$ Carbon black Black Pearls 2000 (Cabot). ${ }^{f}$ JRC-ZRO-2. ${ }^{g}$ P-25, Deggusa. ${ }^{h}$ JRC-

CEO-2. ${ }^{i} \mathrm{JRC}-\mathrm{ALO}-2 .{ }^{j} 10 \mathrm{mmol}(1.36 \mathrm{~g})$ of 1 was used (S/C = 1000). ${ }^{k}$ $280{ }^{\circ} \mathrm{C}, 2$ h. ${ }^{l} 240{ }^{\circ} \mathrm{C}, 10 \mathrm{~h} .{ }^{m}$ Without water, $280{ }^{\circ} \mathrm{C}, 4 \mathrm{~h}$.

15 The hydrodeoxygenation of guaiacols and syringols was also studied with $\mathrm{Pt} / \mathrm{AC}(\mathrm{N})$ catalyst in water solvent (Table 2). Under the conditions (4 $\mathrm{MPa} \mathrm{H}_{2}, \quad 280{ }^{\circ} \mathrm{C}, \quad 6 \mathrm{~h}$ ), 4propylguaiacol (6), 4-allylguaiacol (7), and 4acetonylguaiacol (8) were efficiently converted to 20 propylcyclohexane $\mathbf{2}$ in $65-78 \%$ yields (entries 16-18, Fig. S5). A derivative of syringol, 4-allyl-2,6-dimethoxyphenol (9), also afforded 2 in 58\% yield (entry 19). In these reactions, the methoxy group was hydrolyzed to give methanol in $2-3 \%$ yields. ${ }^{7,8}$ The low yields of methanol might be due to its 25 evaporation or decomposition. In addition, propylcyclopentane (10) with a shorter carbon-chain (C8) was obtained in $5-10 \%$ yields possibly via skeletal isomerization and hydrogenolysis of cycloalkane. ${ }^{7,8}$ Without the solvent, the reaction of $\mathbf{6}$ gave the hydrodeoxygenation products $\mathbf{2}$ and $\mathbf{1 0}$ 30 in good yields at $300{ }^{\circ} \mathrm{C}$ (entry 20). ${ }^{11}$ The formation of small amounts of $\mathbf{1}$ and $\mathbf{5}$ from $\mathbf{6}$ suggests the aromatic $\mathrm{C}-\mathrm{O}$ bond cleavages under the solvent-free conditions. ${ }^{12}$ These results indicate that this catalyst system is applicable to the upgrading of various phenolic bio-oils into cycloalkanes.
Table 2 Hydrodeoxygenation of bio-derived phenolic oils with $\mathrm{Pt} / \mathrm{AC}(\mathrm{N})$ catalyst. $^{a}$

Entry

${ }^{a}$ Reaction conditions: substrate $(2.0 \mathrm{mmol}), 2 \mathrm{wt} \% \mathrm{Pt} / \mathrm{AC}(\mathrm{N})(98 \mathrm{mg}, \mathrm{S} / \mathrm{C}$ $40=200)$, water $(40 \mathrm{~mL})$, initial $\mathrm{H}_{2}$ pressure at $\mathrm{RT}=4 \mathrm{MPa}, 280{ }^{\circ} \mathrm{C}, 6 \mathrm{~h}$,

stirred at $600 \mathrm{rpm} .{ }^{b}$ Yield based on carbon. ${ }^{c} 6(10 \mathrm{mmol}, 1.66 \mathrm{~g}), 2 \mathrm{wt} \%$ $\mathrm{Pt} / \mathrm{AC}(\mathrm{N})(488 \mathrm{mg}, \mathrm{S} / \mathrm{C}=200)$, without water, $300^{\circ} \mathrm{C}, 24 \mathrm{~h}$.

The reusability of $\mathrm{Pt} / \mathrm{AC}(\mathrm{N})$ catalyst was tested for the 45 aqueous-phase reaction of 4-propylphenol (1) at $280{ }^{\circ} \mathrm{C}$ with the $\mathrm{S} / \mathrm{C}$ ratio of 1000 . After the first reaction (Table 1 , entry 13), Pt/AC(N) was recovered by centrifugation, which was successively subjected to the reuse experiments to give $\mathbf{2}$ in $>99 \%$ yields (Fig. 1a and Table S2 in ESI $\dagger$ ). The $\mathrm{pH}$ of the 50 aqueous solution after the first reaction was neutral $(\mathrm{pH}=7.0)$, showing no leaching of acid components from the $\mathrm{Pt} / \mathrm{AC}(\mathrm{N})$ catalyst. The experiments under the solvent-free conditions also demonstrated the reusability of $\mathrm{Pt} / \mathrm{AC}(\mathrm{N})$ catalyst (Fig. $1 \mathrm{~b}$ and Table S2 in ESI $\dagger$ ). The XRD patterns of the recovered ${ }_{55} \mathrm{Pt}$ catalysts showed that the $\mathrm{Pt}$ nanoparticles still retained their small sizes $(<2 \mathrm{~nm})$ (Fig. S6 in ESI $\dagger$ ), thus indicating that the catalysts were durable under the catalytic conditions.
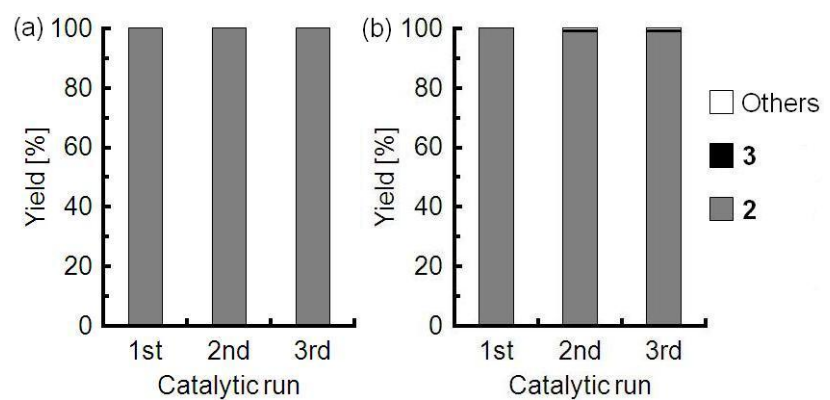

${ }_{60}$ Fig. 1 Reuse experiments in the hydrodeoxygenation of 4-propylphenol (1) to propylcyclohexane (2) by $\mathrm{Pt} / \mathrm{AC}(\mathrm{N})$ in water (a) and under solventfree conditions (b). Reaction conditions: see, entries 13 and 15 in Table 1.

To elucidate the reaction pathway from $\mathbf{1}$ to $\mathbf{2}$, the hydrodeoxygenation of intermediate $\mathbf{3}$ was also investigated 65 (Table 3). ${ }^{13}$ Without catalyst, 3 was dehydrated to form 4 propylcyclohexene (11) in $11 \%$ yield (entry 21 ), suggesting that the dehydration was catalyzed by in-situ generated protons $\left(\mathrm{p} K_{\mathrm{w}}=11.2\right.$ at $\left.280{ }^{\circ} \mathrm{C}\right) .{ }^{14-16}$ Accordingly, the addition 
of a base into the reaction completely suppressed the formation of $\mathbf{1 1}$ (entry 22). The Pt/carbon catalysts in Table 3 greatly promoted the conversion of $\mathbf{3}$ to $\mathbf{2}$, and among the tested catalysts, Pt/AC(N) afforded the highest yield of $\mathbf{2}$ 5 (entry 23, 95\%). Even in the presence of base, the reaction by $\mathrm{Pt} / \mathrm{AC}(\mathrm{N})$ gave 2 in good yield (entry 28). The promotional effect is probably due to the enhancement of $\mathrm{C}-\mathrm{O}$ bond hydrogenolysis by $\mathrm{Pt} /$ carbon $^{17}$

10 Table 3 Hydrodeoxygenation of 4-propylcyclohexanol (3) in water. ${ }^{a}$

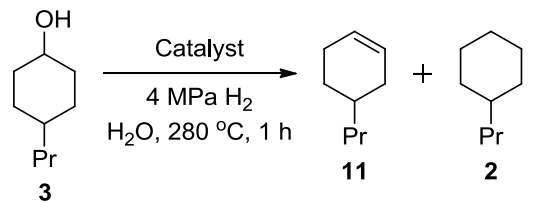

\begin{tabular}{llccc}
\hline Entry & \multicolumn{1}{c}{ Catalyst } & $\begin{array}{c}\text { Conversion } \\
(\%)\end{array}$ & $\mathbf{1 1}$ & $\mathbf{2}$ \\
\hline 21 & No catalyst & 15 & 11 & 0 \\
22 & No catalyst $^{b}$ & 2 & 0 & 0 \\
23 & $\mathrm{Pt} / \mathrm{AC}(\mathrm{N})$ & 100 & 0 & 95 \\
24 & $\mathrm{Pt} / \mathrm{CMK}-3$ & 99 & 0 & 82 \\
25 & $\mathrm{Pt} / \mathrm{MWCNT}$ & 97 & 0 & 87 \\
26 & $\mathrm{Pt} / \mathrm{AC}(\mathrm{W})$ & 64 & 0 & 55 \\
27 & $\mathrm{Pt} / \mathrm{BP} 2000$ & 100 & 0 & 84 \\
28 & $\mathrm{Pt} / \mathrm{AC}(\mathrm{N})^{b}$ & 66 & 0 & 58
\end{tabular}

$15{ }^{a}$ Reaction conditions: 4-propylcyclohexanol ( $\left.2.0 \mathrm{mmol}\right)$, Pt catalyst (2 wt $\% \mathrm{Pt}, 98 \mathrm{mg}, \mathrm{S} / \mathrm{C}=200)$, water $(40 \mathrm{ml})$, initial $\mathrm{H}_{2}$ pressure at $\mathrm{RT}=4$ $\mathrm{MPa}, 280{ }^{\circ} \mathrm{C}, 1 \mathrm{~h}$, stirred at $600 \mathrm{rpm} .{ }^{b} \mathrm{CaCO}_{3}(4.0 \mathrm{mmol}), \mathrm{pH}=10$.

In summary, we have developed a highly efficient carbon20 supported Pt catalyst for the hydrodeoxygenation of phenols under acid-free conditions. The Pt/AC(N) catalyst is prepared from readily available $\mathrm{AC}(\mathrm{N})$ support and is reusable without loss of catalytic activity. The detailed mechanism and the practical application to lignin are now under study.

25 This work was financially supported by JSPS KAKENHI (20226016)

\section{Notes and references}

Catalysis Research Center, Hokkaido University, Kita 21 Nishi 10, Kitaku, Sapporo, Hokkaido 001-0021, Japan. Fax: +81-11-706-9139; Tel: 30 +81-11-706-9140; E-mail: fukuoka@cat.hokudai.ac.jp

$\dagger$ Electronic Supplementary Information (ESI) available: Detailed preparation, catalytic reaction, characterization methods including XRD patterns, TEM images and $\mathrm{N}_{2}$ adsorption results in this work. See DOI: $10.1039 / \mathrm{b} 000000 \mathrm{x} /$

35

1 (a) M. Stöcker, Angew. Chem. Int. Ed., 2008, 47, 9200; (b) D. C. Elliott, Energy Fuels, 2007, 21, 1792; (c) G. W. Huber, S. Iborra and A. Corma, Chem. Rev., 2006, 106, 4044; (d) D. Mohan, C. U. Pittman, Jr. and P. H. Steele, Energy Fuels, 2006, 20, 848; (e) S. 40 Czernik and A. V. Bridgwater, Energy Fuels, 2004, 18, 590; (f) A. V. Bridgwater and G. V. C. Peacocke, Renewable Sustainable Energy Rev., 2000, 4, 1; (g) D. S. Scott, P. Majerski, J. Piskorz and D. Radlein, J. Anal. Appl. Pyrol., 1999, 51, 23.
2 J. Zakzeski, P. C. A. Bruijnincx, A. L. Jongerius and B. M. 45 Weckhuysen, Chem. Rev., 2010, 110, 3552 and references cited therein.

3 (a) D. J. Nowakowski, A. V. Bridgwater, D. C. Elliott, D. Meier and P. de Wild, J. Anal. Appl. Pyrol., 2010, 88, 53; (b) C. Amen-Chen, H. Pakdel and C. Roy, Bioresour. Technol., 2001, 79, 277; (c) P. F. 50 Britt, A. C. Buchanan, III, M. J. Cooney and D. R. Martineau, J. Org. Chem., 2000, 65, 1376; (d) D. Meier, R. Ante and O. Faix, Bioresour. Technol., 1992, 40, 171; (e) P. Zuman and E. B. Rupp, Collect. Czech. Chem. Commun., 2001, 66, 1125.

4 (a) E. Furimsky, Appl. Catal. A: Gen., 2000, 199, 147; (b) M. J.

$55 \quad$ Girgis and B. C. Gates, Ind. Eng. Chem. Res., 1991, 30, 2021.

5 (a) E. Furimsky and F. E. Massoth, Catal. Today, 1999, 52, 381; (b) A. Centeno, E. Laurent and B. Delmon, J. Catal., 1995, 154, 288; (c) E. Laurent and B. Delmon, J. Catal., 1994, 146, 281; (d) E. Laurent and B. Delmon, Ind. Eng. Chem. Res., 1993, 32, 2516; (e)

60 A. Vuori, A. Helenius and J. B-S. Bredenberg, Appl. Catal., 1989, 52, 41 .

6 (a) W. Wang, Y. Yang, H. Luo, T. Hu and W. Liu, Reac. Kinet. Mech. Cat., 2011, 102, 207; (b) N. Yan, Y. Yuan, R. Dykeman, Y. Kou and P. J. Dyson, Angew. Chem. Int. Ed., 2010, 49, 5549; (c) S. Echeandia, P. L. Arias, V. L. Barrio, B. Pawelec and J. L. G. Fierro, Appl. Catal. B: Environ., 2010, 101, 1; (d) D.-Y. Hong, S. J. Miller, P. K. Agrawal and C. W. Jones, Chem. Commun., 2010, 46, 1038; (e) V. A. Yakovlev, S. A. Khromova, O. V. Sherstyuk, V. O. Dundich, D. Y. Ermakov, V. M. Novopashina, M. Y. Lebedev, O. Bulavchenko and V. N. Parmon, Catal. Today, 2009, 144, 362; (f) A Gutierrez, R. K. Kaila, M. L. Honkela, R. Slioor and A. O. I. Krause, Catal. Today, 2009, 147, 239; (g) S. Ramanathan and S. T. Oyama, J. Phys. Chem., 1995, 99, 16365.

7 (a) C. Zhao, Y. Kou, A. A. Lemonidou, X. Li and J. A. Lercher, 75 Angew. Chem. Int. Ed., 2009, 48, 3987; (b) C. Zhao, J. He, A. A. Lemonidou, X. Li and J. A. Lercher, J. Catal., 2011, 280, 8.

8 C. Zhao, Y. Kou, A. A. Lemonidou, X. Li and J. A. Lercher, Chem. Commun., 2010, 46, 412.

9 S. Jun, S. H. Joo, R. Ryoo, M. Kruk, M. Jaroniec, Z. Liu, T. Ohsuna $80 \quad$ and O. Terasaki, J. Am. Chem. Soc., 2000, 122, 10712.

10 In the case of $\mathrm{Rh} / \mathrm{AC}(\mathrm{N})$ (Table 1, entry 10), propylcyclopentane $(<1 \%)$ was formed, but no other products were observed on GC of the liquid and gas phases. In the reaction of $\mathrm{Ru} / \mathrm{AC}(\mathrm{N})$ (entry 11), propylcyclopentane $(11 \%), 2$-methylpropylcyclopentane $(8 \%)$, and some unidentified products were detected in the liquid phase, where the total carbon yield in the liquid phase was $86 \%$. Methane $(3 \%)$ was observed in the gas phase.

11 In this reaction, $\mathbf{1}(1 \%), \mathbf{3}(<1 \%), \mathbf{5}(<1 \%)$, 2-methoxy-4propylcyclohexanol $(<1 \%), 2$-methylpropylcyclo-pentane $(1 \%)$, methane $(3 \%)$, and minor unidentified products were observed.

12 (a) T. Nimmanwudipong, R. C. Runnebaum, D. E. Block and B. C. Gates, Catal. Lett., 2011, 141, 779; (b) X. Zhu, L. L. Lobban, R. G. Mallinson and D. E. Resasco, J. Catal., 2011, 281, 21.

13 When the reaction of $\mathbf{3}$ was performed with $\mathrm{Pt} / \mathrm{AC}(\mathrm{N})$ under $1 \mathrm{~atm}$ 95 of $\mathrm{He}$ atmosphere, the dehydrogenation of $\mathbf{3}$ gave a mixture of 4propylphenol $1(15 \%)$ and 4-propylcyclohexanone $4(10 \%)$ together with propylcyclohexane $\mathbf{2}(2 \%), \mathbf{3}(57 \%)$, and propylbenzene $\mathbf{5}(1 \%)$. Thus, the reaction of $\mathbf{3}$ was carried out under pressurized $\mathrm{H}_{2}$ to evaluate the hydrogenolysis ability of the Pt/carbon catalysts.

10014 (a) N. Akiya and P. E. Savage, Chem. Rev., 2002, 102, 2725; (b) P. E. Savage, Chem. Rev., 1999, 99, 603; (c) W. L. Marshall and E. U. Franck, J. Phys. Chem. Ref. Data, 1981, 10, 295.

15 (a) N. Akiya and P. E. Savage, Ind. Eng. Chem. Res., 2001, 40, 1822; (b) B. Kuhlmann, E. M. Arnett and M. Siskin, J. Org. Chem., 1994, 59, 3098 .

16 (a) M. J. Antal, Jr., M. Carlsson and X. Xu, Ind. Eng. Chem. Res., 1998, 37, 3820; (b) X. Xu and M. J. Antal, Jr., Ind. Eng. Chem. Res., 1997, 36, 23; (c) X. Xu and M. J. Antal, Jr., AIChE J., 1994, 40, 1524.

$11017 \mathrm{NH}_{3}$-TPD profiles of $\mathrm{Pt} / \mathrm{AC}(\mathrm{N})$ and $\mathrm{AC}(\mathrm{N})$ showed no peak, suggesting that $\mathrm{Pt} / \mathrm{AC}(\mathrm{N})$ and $\mathrm{AC}(\mathrm{N})$ had no acidity (Fig. S7 in $\mathrm{ESI} \dagger)$. Therefore, acid-catalysis of $\mathrm{Pt} / \mathrm{AC}(\mathrm{N})$ in the reaction of $\mathbf{3}$ can be excluded. 